\title{
A Study on the Tax Obligations and Perceived Tax Compliance of Small and Medium Enterprises (SMES) in Gia Lam, Hanoi
}

\section{Nguyen Thi Huong, Dao Thi Hoang Anh, Dang Thi Hai Yen, Bui Thi Hong Nhung \& Le Thi Thanh Hao}

Faculty of Accounting and Business Management, Vietnam National University of Agriculture, Hanoi 131000, Vietnam

\begin{abstract}
This study was conducted to examine general information of the tax obligations and perceived tax compliance of small and medium enterprises (SMEs) in Gia Lam - Hanoi. In this study, 150 SMEs were selected randomly and analyzed using descriptive analyses and principal component analysis (PCA). The results showed that most SMEs owners were men who had an average age of 39 and an average management experience of 7 years. The average number of laborers was 15 people and the total assets and revenue were 72.22 and 103.84 billion VND, respectively. SMEs reported having difficulties registering, declaring, and paying taxes, and nearly half of them had submitted taxes lately. Moreover, the perceived tax compliance of the enterprises could be divided into five key factors, namely quality of tax services, social norms, technology application, enterprise responsibility, and quality of tax officials. Based on these results, recommendations are given to the tax authorities in order to improve some tax regulations and policies.
\end{abstract}

\section{Keywords}

Tax compliance, tax obligations, Principal Component Analysis (PCA)

\section{Introduction}

In most countries, taxes are mandatory for all economic organizations and are also the largest proportion of revenue in national budgets. Tax compliance remains a top concern for most governments around the world. The situation of tax non-compliance has caused negative impacts, leading to losses of budget revenue, and

Received: June 12, 2020

Accepted: October 30, 2020

Correspondence to nguyenhuong@vnua.edu.vn inequality in competition and business activities. According to a recent report, Vietnam has nearly 517,900 existing enterprises, of which small and medium enterprises (SMEs) account for about $98 \%$ (General Statistics Office, 2018). SMEs have been the primary driver 
of socio-economic growth of the country as they create up to $40 \%$ of the GDP, and create more than one-million new jobs every year (General Statistics Office, 2018). The enterprises contribute approximately $39.55 \%$ of the total state budget revenue (General Statistics Office, 2019). However, outstanding tax debts have grown recently. For example, the tax debts of enterprises were 82,972 billion VND in 2019, an increase of $8.7 \%$ compared to 2018 , in which the tax debt of SMEs is the primary concern (General Department of Taxation, 2019). Managing tax compliance is a major challenge for governments and tax authorities in developing countries, including Vietnam. Many studies have shown that in developing countries, the actual tax revenue is less than half of the potential taxes that should contribute to the state budget (Gandhi et al., 1987). Therefore, governments and tax authorities need to consider the factors affecting tax compliance to ensure the transparency, fairness, and efficiency of the tax system.

Up to 2019, Gia Lam had 4,664 enterprises, of which there were 2,156 SMEs, accounting for $46.2 \%$ of the total number of enterprises. The SMEs in Gia Lam can be classified as commercial enterprises $(53.3 \%)$, manufacturing enterprises (16.6\%), service enterprises (13.3\%), and general enterprises $(16.8 \%)$ (combined production and trade). SMEs contribute more than $30 \%$ of the total budget revenue, create more jobs, and ensure the social security of the district (Le Thi Minh Chau \& Hoang Thi Mai Anh, 2019). However, 615 SMEs, which account for about $28.5 \%$ of the total number of SMEs, had violations in tax obligations (Hanoi Tax Department, 2019). This research aimed to figure out the situation of tax liability performance and awareness of tax obligations and tax compliance of SMEs in Gia Lam district - Hanoi and make some recommendations to improve the regulations and policies of the tax system.

\section{Methodology}

\section{Data collection}

The research was carried out in Gia Lam, which is a suburban district located in the easternmost region of Hanoi, Vietnam. The district is divided into 20 communities and two towns with an area of $108.44 \mathrm{~km}^{2}$. As of 2019, the population was 277,600 people (General Statistics Office, 2019). Recently, the urbanization process has grown rapidly in the district with the emergence of a series of new urban areas, such as Dang Xa urban area and Vinhomes Ocean Park urban area.

The questionnaire survey was conducted randomly among 150 SMEs in September 2019. The questionnaire was divided into two parts:

Part 1 included issues related to general information about the SMEs: age, gender, education, and management experience of the enterprise's owners.

Part 2 consisted of 16 factors reflecting the enterprises' perceptions of tax compliance. These factors were selected based on previous tax compliance studies by Alan (1996), Cummings et al. (2009), Nicolate (2011), Helhel \& Ahmed (2014), and some other non-published research. The consequences of tax compliance were rated on a Likert-type scale ranging from 1 to 5 in which 1 represented a very low impact and 5 represented a very high impact.

Secondary data were collected from three tax authorities, the Gia Lam Tax Authority, the Hanoi Tax Authority, and the General Department of Taxation, and the financial statements of the selected enterprises.

\section{Data analysis}

Descriptive statistics were used to determine each enterprise's tax liability performance.

Principal component analysis (PCA) was used to identify the groups of factors affecting the tax compliance of the enterprises. Principal factor analysis is a method used in multivariate analysis to find and retain key factors. The two main steps to perform a PCA were completed as follows:

Step 1: The correlation matrix, specific vectors, and individual values (initial transmission factor) were calculated.

Step 2: The VARIMAX rotation was used to clarify and explain the factor groups better.

The transmission coefficient indicates how a variable contributes to a major factor. All 
components that had a specific value $\geq 1$ were retained (Hair et al., 2010). In order to ensure significant results of the analysis, a sample size of $\geq 100$ and loading coefficients with values $\geq 0.5$ were selected (Hair et al., 2010). All analyses were carried out using STATA for Windows (v.13.1).

\section{Results and Discussion}

\section{Socio-economic characteristics of SMEs}

Most SMEs owners were male and all of them had obtained at least a bachelor's degree from a college or university. The details of the socio-economic characteristics of the selected SMEs are shown in Table 1.

The SMEs owners had an average age of 39.2 , of which the youngest owner was 33 . These values were relatively consistent with the average age of business owners from 30-50 years old (Tran Thi Xuyen, 2020). The average experience of management was about 7 years, including some SMEs that had just been established.

The average total assets and average revenue of these SMEs were 72.22 and 103.84 billion VND, respectively. The average number of laborers in the SMEs was around 15 people. Such SMEs could face difficulties in expanding their businesses due to a lack of capital, human resources, and access to credit.

\section{Fulfilling tax obligations of SMEs}

SMEs in Gia Lam district have to fulfill several tax obligations: corporate income tax,

Table 1. Socio-economic characteristics of SMEs

\begin{tabular}{lcccc}
\hline \multicolumn{1}{c}{ Category } & Unit & Mean & Std. Dev. & Max \\
\hline $\begin{array}{l}\text { Age of owner } \\
\begin{array}{l}\text { Owner's } \\
\text { experience }\end{array}\end{array}$ & Year & 39.20 & 4.52 & 33.00 \\
$\begin{array}{l}\text { No. laborers } \\
\text { Total assets }\end{array}$ & Year & 6.90 & 3.47 & 1.00 \\
Reople & Million VND & 72.22 & 20.3 & 3.00 \\
Revenue in 2018 & Million VND & 103.84 & 32.85 & 118.96 \\
\hline
\end{tabular}

Table 2. Tax obligations of SMEs

\begin{tabular}{|c|c|c|}
\hline \multicolumn{2}{|c|}{ Categories } & \multirow{2}{*}{$\begin{array}{c}\text { Respondents (\%) } \\
36.67\end{array}$} \\
\hline & Complicated and overlapped & \\
\hline rax registration process & Accessable & 63.33 \\
\hline \multirow{2}{*}{ Tax declaration method } & Stable & 35.33 \\
\hline & Changed & 64.67 \\
\hline \multirow{2}{*}{ Complex tax } & Corporate income tax and VAT & 75.33 \\
\hline & Others & 24.67 \\
\hline \multirow{2}{*}{ VAT refund } & Sometimes & 25.33 \\
\hline & Never & 74.67 \\
\hline \multirow{2}{*}{ Tax delayed } & Sometimes & 49.33 \\
\hline & Never & 50.67 \\
\hline \multirow{2}{*}{ Source of tax information } & Internet & 46.00 \\
\hline & Tax authorities & 54.00 \\
\hline
\end{tabular}


excise tax, value-added tax, special consumption tax, and import tax. The enterprises reported often having difficulty in all 3 stages of registration, declaration, and payment of taxes. Table 2 shows the details of the tax obligations of SMEs in Gia Lam.

Among the total respondents, $36.67 \%$ said that the tax registration process still had many complicated and overlapping procedures, which made the process difficult for them to complete. Meanwhile, about $64.67 \%$ of the enterprises said that the tax declaration method sometimes changed, they constantly had to update software, and the web portals of the General Department of Taxation were inaccessible. The enterprises were also not fully instructed when there was a change in tax law. When fulfilling tax obligations, $75.33 \%$ of the enterprises said that corporate income tax and value-added tax were two complex and difficult taxes to implement and they needed support from the tax authorities. For value-added tax, $25.33 \%$ of the enterprises were entitled to tax refunds, but they all assessed the complicated tax refund procedures and tax officials as causing difficulties for them. Almost half $(49.33 \%)$ of the enterprises have sometimes delayed paying taxes. The main reason given by enterprises is that they were in a difficult business period. In addition, a number of enterprises said that their accounting staff delayed settlement leading to delayed tax payment. The majority of the respondents had quick access to changes in tax regulations, but $46 \%$ of them rated that the source of information was accessed through the internet. Tax services and tax authorities need to play a leading role in providing information to enterprises.

\section{Perception of tax conpliance of SMEs}

Sixteen components were selected reflecting the perception of tax compliance of taxpayers in Gia Lam district - Hanoi. Table 3 shows the average values and the standard deviations of the components on a five-point Likert scale and the PCA results. The KMO test $=0.65$, so the data used in the PCA were relevant and significant.

The second and third columns of Table 3 show that with an average of 4.37 , the enterprises were highly aware of their tax obligations and responsibilities to the state. They paid taxes because they trusted the government's operations. With an average value of 3.76, most enterprises agreed that "tax rates are too high". They also agreed that tax systems are complex and unfair. Research by Helhel \& Ahmed (2014) also showed that taxpayers in general in Yemen gave the highest scores for "tax rates are too high" and "the tax system is not fair". Tax compliance of taxpayers was also affected by non-taxpayers and a popular excuse was, "why am I paying taxes while people are evading taxes"?

The second part of Table 3 shows the analysis results of the PCA. It can be seen that the enterprises' perception of tax compliance is divided into 5 main components (5 groups).

Component 1 can be named quality of tax services and is shown at the transmission coefficient of 0.50 with "considering the requirements of taxpayers when formulating tax policies". As can be seen, enterprises really need tax authorities to pay attention to their opinions when developing tax policies.

Component 2 has a loading of 0.50 with "taxpayers affected by people who are not willing to pay taxes" and can be called social norms. This shows that enterprises always compare and observe others. If other enterprises do not pay taxes or do not have to pay taxes, the SMEs will tend not to pay or evade paying taxes. Previous studies of Van Cong Tuan (2012), Dang Thi Bach Van (2014), Pham Thi My Dung \& Le Quoc Hieu (2015), and Bui Ngoc Toan (2017) also indicated that "social norms" was one of the significant factors impacting tax compliance.

Component 3 can be named technology application with a very high loading of 0.63 for "application of technology in tax registration, declaration and payment". It can be seen that enterprises need tax authorities to apply technology in the registration, declaration, and payment of taxes so that they can save time and avoid complicated administrative procedures. In practice, the application of technology has been playing an ever increasing role in public services operation, especially in tax administration. Technology application saves administrative costs for tax authorities, thereby minimizing 
Table 3. Average values and standard deviations of components in the PCA on perceived tax compliance at the selected SMEs

\begin{tabular}{|c|c|c|c|c|c|c|c|}
\hline \multirow{2}{*}{ Components } & \multirow{2}{*}{ Mean } & \multirow{2}{*}{ S.D } & \multicolumn{5}{|c|}{ Main components (PCA) } \\
\hline & & & 1 & 2 & 3 & 4 & 5 \\
\hline The effect of public spending & 3.00 & 1.13 & 0.46 & -0.12 & 0.05 & -0.01 & -0.05 \\
\hline Consider the requirements of taxpayers when developing tax policies & 2.76 & 1.21 & 0.50 & 0.09 & 0.05 & 0.05 & 0.15 \\
\hline Taxpayers usually do not pay the exact amount of tax due & 2.63 & 0.86 & 0.01 & -0.02 & -0.30 & 0.24 & 0.47 \\
\hline $\begin{array}{l}\text { Dissemination of psychology "why do I pay taxes while people are } \\
\text { evading taxes" }\end{array}$ & 3.63 & 0.86 & -0.02 & 0.45 & 0.21 & 0.32 & 0.20 \\
\hline Taxpayers are affected by people who are not willing to pay taxes & 3.75 & 0.83 & -0.21 & 0.50 & 0.07 & -0.12 & -0.05 \\
\hline Paying tax is the obligation of the business & 4.37 & 0.49 & 0.33 & 0.09 & -0.09 & 0.51 & 0.01 \\
\hline Paying taxes reflects trust in the government's operations & 3.62 & 0.99 & -0.10 & -0.05 & 0.24 & 0.49 & -0.05 \\
\hline Tax rates are too high & 3.76 & 1.20 & 0.25 & 0.22 & 0.15 & -0.43 & 0.00 \\
\hline The current tax system is not suitable for business conditions & 3.38 & 0.70 & 0.10 & -0.19 & 0.24 & -0.29 & 0.17 \\
\hline The tax system is complex and unfair & 3.63 & 0.70 & 0.04 & 0.28 & -0.18 & -0.14 & 0.27 \\
\hline Frequency of tax inspections & 2.75 & 1.31 & -0.44 & 0.09 & 0.11 & 0.08 & 0.12 \\
\hline Tax sanctions are not enough of a deterrent & 2.37 & 1.00 & 0.21 & -0.13 & 0.43 & 0.12 & -0.12 \\
\hline Extensive tax exemptions lead to inequality & 3.13 & 1.18 & 0.14 & 0.52 & -0.04 & -0.03 & -0.17 \\
\hline Professional knowledge of tax officials & 2.89 & 0.78 & -0.15 & -0.21 & 0.27 & -0.02 & 0.50 \\
\hline Working attitude of tax officials & 3.39 & 0.99 & 0.13 & 0.08 & -0.02 & -0.12 & 0.54 \\
\hline $\begin{array}{l}\text { Application of technology in tax registration, declaration, and } \\
\text { payment }\end{array}$ & 2.38 & 0.70 & -0.04 & 0.12 & 0.63 & -0.01 & 0.04 \\
\hline
\end{tabular}

Note: Loadings of $|0.5|$ are in bold. Component 1: Quality of tax services; Component 2: Social norms; Component 3: Technology application; Component 4: Enterprise responsibility; and Component 5: Quality of tax officials.

interactions between tax authorities and taxpayers.

Component 4 shows the enterprise responsibility with a loading of 0.51 for "paying tax is the obligation of the business", which indicates that enterprises are aware that paying taxes is their responsibility.

Component 5 can be named quality of tax officials with loadings of 0.50 and 0.54 for "professional knowledge of tax officials" and "working attitude of tax officials", respectively. The quality of the tax office staff plays an important role in corporate tax awareness. Such results are also consistent with those of previous studies by Nguyen Thi Le Thuy (2009), Van Cong Tuan (2012), and Bui Ngoc Toan (2017). It can be infered that tax officials need to improve their skills and attitudes to meet the enterprises' requirements.
Pham Thi My Dung \& Le Quoc Hieu (2015) also showed that the perception of tax compliance could be divided into six main components, including quality perception, tax services, structure of the tax system, and social norms. However, our research pointed out that the quality of tax officials and the enterprises' responsibility also played very important roles in the perception of tax compliance.

\section{Conclusions}

Enterprises in this study strongly perceived their obligations and responsibilities for paying taxes. Most taxpayers agreed with the statements that "tax rates are too high" and that there is a "complex and unfair tax system". The perception of tax compliance was divided into 5 main components, namely quality of tax services, 
social norms, technology application, enterprise responsibility, and quality of tax officials.

Based on the results, this study provides some implications for tax authorities to complete their regulations and policies, and create conditions for enterprises to fulfill their tax obligations. First of all, tax authorities need to act as the official information provider, answering the problems of taxpayers. In addition, the regulations and order of implementation need to be promulgated synchronously and unified among relevant tax authorities. Tax authorities also need to consider an enterprise's views when developing tax policies and laws. Moreover, the tax authorities need to enhance the application of technology in tax registration, declaration, and payment. At the same time, the tax authorities need to improve their professional quality as well as standardize the tax officials.

These are required interventions from a policy point of view. Tax compliance could be reinforced if taxpayers received better public services or if they responded positively to social norms. Moreover, there is a significant impact on tax compliance when the government and tax authorities apply modern techniques in fulfilling tax obligations.

\section{References}

Alan H. P. (1996). The Determinants of Individual Income Tax Compliance. Internal Revenue Service division, Washington D.C.

Bui Ngoc Toan (2017). Factors affecting income tax compliance behavior of companies - experimental research in Hochiminh City. Journal of Science - Hue University. 5A: 77-88 (in Vietnamese).

Cummings R. G., Vazquez J. M., McKee M. \& Torgler B. (2009). Tax morale affects tax compliance: Evidence from surveys and an artefactual field experiment. Journal of Economic Behavior and Organization. 70: 447-457.

Dang Thi Bach Van (2014). Taxpayers issues and tax compliance, Journal of Development \& Integration. 16(26): 59-63 (in Vietnamese).

Gandhi V. P., Ebrill L. P., Shome P., Anton L. A. M., Modi J. R., Sanchez-Ugarte F. J. \& Mackenzie G. A. (1987). Supply-side tax policy: Its relevance to developing countries. International Monetary Fund. 140-172. DOI: 10.5089/9780939934911.071.

General Department of Taxation (2019). Report 2019 (in Vietnamese).

General Statistics Office (2019). Report 2019 (in Vietnamese).

General Statistics Office (2018). Report 2018 (in Vietnamese).

Hair J., Black W., Babin B. \& Anderson R. (2010). Multivariate Data Analysis. Upper Saddle River, New Jersey: Prentice- Hall.

Hanoi Tax Department (2019). Delinquent Taxpayers list. Retrieved from http://hanoi.gdt.gov.vn/wps/portal/Report on October 21, 2020 (in Vietnamese).

Helhel Y. \& Ahmed Y. (2014). Factors Affecting Tax Attitudes and Tax Compliance: A Survey Study in Yemen. European Journal of Business and Management. 6(22): 48-57.

Le Thi Minh Chau \& Hoang Thi Mai Anh (2019). Presentation of financial statements in some small and medium enterprises in Gia Lam district - Hanoi. Journal of accounting and auditing, 1\&2 (184): 53-55. (in Vietnamese).

Nicolate B. (2011). A review of factors for tax compliance. Economics and Applied Informatics. 17(1): 69-76.

Nguyen Thi Le Thuy (2009). Improving tax collection management of the State to enhance tax compliance of enterprises in Hanoi. PhD thesis - National Economics University.

Pham Thi My Dung \& Le Quoc Hieu (2015). Factors affecting corporate tax compliance. Journal of Finance. 2(7): 11-16 (in Vietnamese).

Tran Thi Xuyen (2020). Vietnam enterprises structure by age group. Retrieved from https://dangkykinhdoanh.gov.vn/vn/tintuc/611/3701/co-cau-doanh-nghiep-viet-nam-phantheo-nhom-tuoi.aspx on October 28, 2020 (in Vietnamese).

Van Cong Tuan (2012). Factors affecting tax compliance of enterprises in District 1 - Ho Chi Minh city. Master thesis - Economics University of Ho Chi Minh City. (in Vietnamese). 